\title{
Practices of Housing Production in Albania in the 1990s and 2000s: Leading Social Integration Processes?
}

\author{
Fereniki VATAVALI*1 \\ * Corresponding author \\ ${ }^{1}$ Hellenic Open University, School of Science and Technology, Athens, GREECE \\ E-mail: fereniki3@hotmail.com \\ DOI: $10.24193 /$ J SSP.2020.1.01
}

https:// doi.org/ 10.24193/J SSP.2020.1.01

Ke y w o r d s: housing, transition, Albania, practices, social integration

\begin{abstract}
A B S T RA C T
The aim of this article is to discuss the transition of housing in Albania from a centrally-planned economy to a free-market economy, by focusing on practices adopted in housing production after the collapse of state socialism in 1989 and until the beginning of the global financial crisis in 2008. The inefficiency of policies and formal market forces to deal with massive urbanization and the demand for housing have led to the dominance of self-constructions, informal activities and exchange practices in housing production. In this sense, documentation of perceptions and experiences of individuals that are active in housing production can contribute to the understanding of housing sector and land development processes. The main argument is that the dynamics of housing sector and adopted practices in the context of transition play an important role for social integration processes in Albania. In terms of methodology, a mixed-method approach has been adopted; analysis of statistical data and institutional reforms were combined with qualitative research on social practices based on interviews.
\end{abstract}

\section{INTRODUCTION}

From 1945 until 1989, housing production in Albania was under state control (Aliaj, 2003). Private property was abolished, land was nationalized, while the right to use land assets was subject to strict conditions. State managed the existing housing stock, regulated access to housing and implemented largescale housing programs in order to meet the needs emerging from the various destructions caused during World War II and the post-war urbanization.

Just like other East European and Balkan countries (Andrusz, 1996; Tosics et al., 2001; Lowe and Tsenkova, 2003; Hamilton et al., 2005) the end of state socialism in 1989 and the transition to a free-market economy have fostered wide changes in housing in Albania (UNECE, 2002; Aliaj, 2003; Vatavali, 2017); these changes are directly related to the significance urban land and housing have acquired during the last decades in global economy and to the recent redefinition of the social role of housing (Harvey, 2010; Hodkinson, 2012; Madden and Marcuse, 2016; Rolnik, 2019).

The collapse of agricultural and industrial production, rapid urbanization and massive emigration (King et al., 2005) in combination with reforms in land property and spatial planning (World Bank, 2006) made the ground instable for economic and social development and led to construction boom and to an intensive activity on the housing market. Apart from sheltering, housing became the main asset of households and high homeownership rates (93\% according to the National Census in 2011) providing security to large segments of the population (Aliaj, 
2008). Housing was also the main field of small and large investments (World Bank, 2007), it involved thousands of construction and commercial companies (SEED, 2002) and stimulated local labor markets (INSTAT, 2004).

Thirty years after the collapse of statesocialism, the post-socialist processes of urban development and housing production in Albania have remained understudied. The reports of international organizations, national policy-makers and foreign experts mainly adopt a macroscopic approach. On the other hand, academic projects that analyze and evaluate experiences and practices of housing production in Albania are not only scarce, but also partial.

The article intends to critically contribute to the discourse on housing transition in Albania, by highlighting the social aspects of housing production. In particular, the aim of this article is to investigate the transition of housing in Albania from a centrallyplanned economy to a free-market economy, by studying practices adopted in housing production. The main argument is that, beyond questions about environmental impacts and climate resilience, the dynamics of Albanian housing sector in the context of transition plays an important role for the social integration processes and for strengthening community relations. The article focuses on the relations between different social groups with emphasis on the interaction of social practices with market forces and promoted policies after the collapse of state socialism and until the beginning of the global financial crisis in 2008.

\section{METHODOLOGY}

The main concern was the adoption of methodological tools that would respond to the particularities of housing production processes in Albania during transition. Formal and informal practices, long-term strategies and ad-hoc choices, visible and invisible relations, coexist and interact with policies, practices and perceptions on land development and housing issues, and so, they create a very dynamic research field. In this context, a mixed-method approach that combines statistical data and analysis of institutional reforms, with qualitative research on the social practices related to housing production was adopted. More specifically, the analysis consists of:

- analysis of statistical data collected from national agencies and international organizations, in order to have an overview of housing sector activity at national level;

- evaluation of the legal framework and policies on land property, land development and spatial planning, illustrating the institutional landscape within and beyond which practices regarding housing production are developed;
- interviews carried out in Albanian cities, mainly in Tirana and Gjirokastër. There were twentynine open-ended semi-structured interviews with representatives of the construction sector (architects, developers, builders, public servants etc) in order to explore and document the various conflicts, synergies and dynamics regarding housing production. Considering that housing sector has been a rather fluid and instable field, informants' experiences and perception provide valuable information for understanding it. Quotes of these interviews were integrated in the article. Anonymising interview data is part of the adopted methodology and an agreed basis between researcher and respondents, in order to guarantee access to highly sensitive context, such as informal and illegal practices.

The fieldwork was conducted from 2006 to 2010, while the article also builds on further research on housing production in Albania until 2017.

\section{RESULTS AND DISCUSSION}

\subsection{Main features of housing production in Albania}

The construction sector in Albania boomed at the beginning of the 1990s. The political instability caused by the collapse of the financial pyramid schemes paused construction activity during 1997, and a new circle of construction activity started in 1998, with a shift towards larger constructions. Since 2008, the construction sector has slipped in recession, as a result of the global financial crisis (Suraj, 2015) (Fig. 1) ${ }^{1}$.

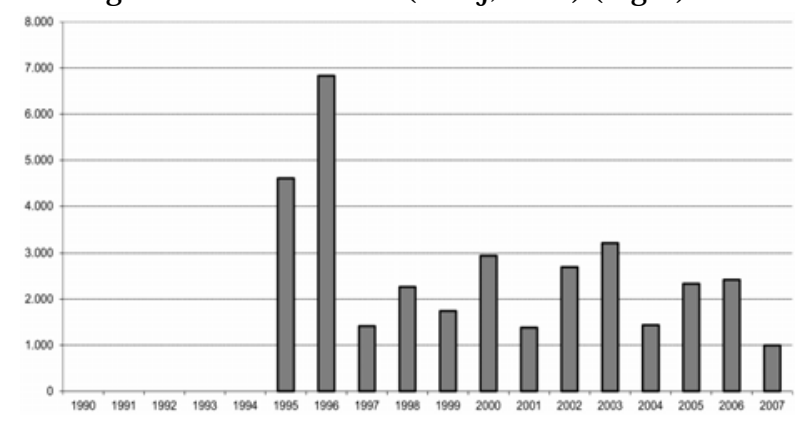

Fig. 1. New buildings in Albania, according to building permits records, 1995-2007 (Source: INSTAT).

Housing is the main field of construction activity (World Bank, 2007). On the one hand, the existing dwellings, especially those constructed in postwar era, are extended and renovated. There is special interest in interventions on the flats of the former-state residential complexes, which, although they are considered old-fashioned, are affordable and are built

${ }^{1}$ Statistical data used for Figures 1, 2 and 3 do not correspond to facts, because of malfunctions of the Albanian state agencies that collect data - particularly in the 1990s - , as well as because a large part of construction activity is informal and therefore it is not recorded. Nevertheless, these figures reflect the dominant trends in construction sector and housing production. There are no data from 1990 until 1994. 
in convenient locations. On the other hand, new housing units are constructed massively (Fig. 2), especially in central Albania and the coastal areas. Single-family dwellings are constructed both in urban and rural areas, through formal or, usually, through informal processes. New apartment buildings are built in the largest cities. These apartments have a wide range of amenities and represent a new lifestyle.

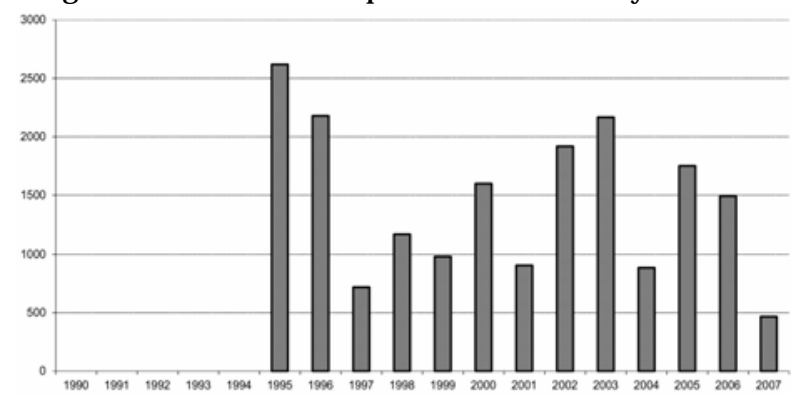

Fig. 2. New residential buildings in Albania, according to building permits records, 1995-2007 (Source: INSTAT).

The growth of investment capital gradually increased the average size of new buildings (Fig. 3) particularly after 1998, with the appearance of the first apartment buildings. In this sense, the increase of the average building size is related with the shift from noncommercial to commercial housing.

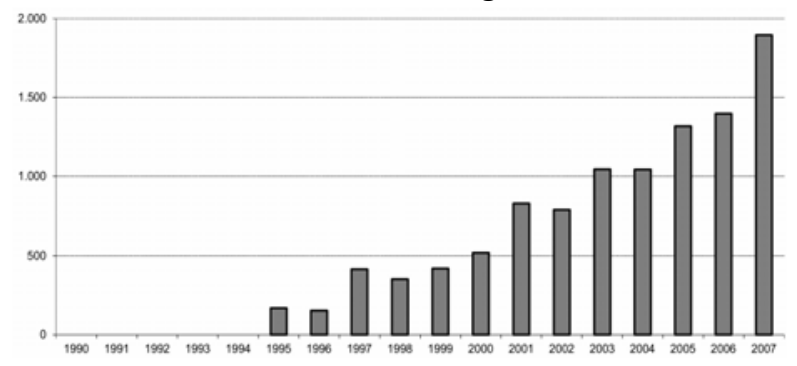

Fig. 3. Average surface (sqm) of new buildings in Albania, 1995-2007 (Source: INSTAT).

Information about the size of housing units is in bits and pieces. Local developers and real-estate agents state that the size of commercial housing units ranges from $50 \mathrm{~m} 2$ to $150 \mathrm{~m} 2$, and usually from $80 \mathrm{~m} 2$ to $100 \mathrm{~m} 2$, much higher than $30 \mathrm{~m} 2$, which was the average size of dwellings before 1989 (Aliaj, 2003). The average number of rooms of each dwelling is between two and four, while the demand for one-room flats is very low due to the structure of households (World Bank, 2007).

\subsection{Practices of housing transition}

The transition of housing to the free-market economy goes hand in hand with the development of practices that respond to the particularities of landproperty system and social relations. Self-constructions, informal activities and exchange practices are dominant in the first years after 1989. These practices are interconnected and cover the inefficiency of policies in dealing with social dynamics, the lack of a strong formal housing market and mainly housing needs.

\subsubsection{Self-constructions: crossing housing sector}

In the context of transition, self-construction practices are a fundamental aspect of construction activity, especially of housing production (UNECE, 2002). They are adopted in the construction of new and the renovation of old dwellings, in some or all construction works of a project, in legal and illegal constructions, as well as in the construction of rural and urban residences.

Self-construction used to be a popular practice in housing production in Albania before 1989, particularly in rural areas (Aliaj, 2003) just like in other socialist countries (Palacin and Shelburne, 2005). Apart from a skill that contributed to the integration to the labour market in Albania or abroad, for many people the experience of self-construction has become a significant asset for the construction or improvement of their own home after 1989. Internal migrants transferred experience from rural to urban areas (UNECE, 2002), while emigration improved construction skills as emigrants, who mainly work in construction industry (King et al., 2005) and encountered new construction models, technologies and materials, imported know-how in Albania (Dalakoglou, 2009, 2010).

Self-construction practices are based on the ties among family members and the relations of solidarity and non-profit exchanges within the community. They reduce the cost of housing, as construction work is implemented by unpaid labour of relatives and friends. Quite often, residential buildings are family projects that, for example, «four brothers with their parents and their kids invest all in one building, one floor for everyone and work together and reduce the cost by putting labour» (B.A., architect, Tirana, 2007).

Self-construction gives the chance to control the progress of construction, but also to proceed to gradual improvements of a building according to the financial capacities of the family and thus «a house is not built in one year, but is completed in ten years, in fifteen years, and all the family gradually invest in it» (B.A., architect, Tirana, 2007). The supply of construction materials is made through family or professional networks and so «high quality and good prices are ensured» (L.K., builder, Sarandë, 2010).

In contrast with several developing countries (UN-HABITAT, 2003) the quality of self-constructed dwellings in Albania is rather high, as «in most cases, professional builders undertake construction works» (M.L., builder, Gjirokastër, 2008). Quite often, the 
quality of self-constructed dwellings is higher than that of commercial flats or residences constructed by contractors on demand, because the cost of construction is reduced by annihilating the cost of work and not the cost of materials, which define the quality of the building.

At the beginning of 1990s, self-construction filled the gap created by the withdrawal of the state from housing production. But even later, when free market was the dominant actor in the housing sector, a large part of the population took advantage of family and community networks in order to access housing. This is so, because commercial housing was unaffordable for many households, but also because emigration had a negative impact on the local labour markets, as «qualified builders have higher profits if they emigrate to Italy or Greece» (F.T., developer, Gjirokastër, 2007).

\subsubsection{Informal housing: a practice without alternatives}

Considering the unclear land property system, the ineffectiveness of the state to control urban development and to promote efficient housing policies, the complexity of the permit authorization processes, the difficulties in legally acquiring land for development and the high prices of the formal real estate market, informal practices have been the main option for a large part of the population to access housing (Deda, 2003; Pengu et al., 2003; Bertaud, 2006; World Bank, 2007; Tsenkova and Antoni, 2017).

Informal housing in Albania is a widespread and multidimensional condition that brings together various actors (de Soto, 2003; Aliaj, 2008; Zhllima and Imami, 2013; Triantis and Vatavali, 2016). It provides high-quality residence in terms of construction, size and location, even to low-income households, in contrast with several developing countries (UN-HABITAT, 2003). More than $60 \%$ of the buildings constructed from 1992 to 1996 in the country were informal (UNECE, 2002), while in 2006 around 350.000 households resided in informal houses, namely around half of the national population (Aliaj, 2008).

Informal practices are adopted in all types of construction projects, regardless of their scale and use, and take various forms. In most cases, settlers acquire the land for new constructions and extensions either through informal transactions and illegal subdivisions, or through squatting undeveloped state-owned land or land with unclear property status (Deda, 2003), as «they know that they won't have any troubles» (S.M. developer, Gjirokastër, 2007).

Large informal settlements consisting of detached or multi-family dwellings developed in the 1990s and 2000s in the peri-urban areas in central Albania «as a collective solution for dealing with housing needs that is based on self-construction» (B.A., architect, Tirana, 2007). New rooms or new floors have been attached to single-family houses, in order to increase living space. In many cases, a new concrete frame attached in many former state apartment buildings received horizontal extensions of all apartments, based on an informal agreement between flat-owners.

Usually the construction of dwellings takes place either without building permits or not in conformity with the approved permits, as- according to a developer- «even if you have a building permit, you don't care about the rules and, for example, you build an extra floor» (F.T., developer, Gjirokastër, 2009). Also, many - often rather luxurious - summer houses in coastal areas are informal, a fact that has recently emerged as a major political issue (Triantis and Vatavali, 2016).

Informal housing is founded on the convergence of interests of various social groups and creates a climate of social consensus. The profits from informal construction activities are high for all actors involved. However, there are significant differentiations, for example between poor homeowners who add a room to their residence and large real-estate developers who add an entire floor to an apartment building.

From the perspective of the central and local government, the tolerance of informality is an implicit social and economic policy, which contributes to covering housing needs and activating the construction sector, thus providing significant political benefits (Tosics et al., 2001).

\subsubsection{Exchange practices in the construction of apartment buildings: between commercial housing and self-construction}

The construction of apartment buildings is usually based on a special exchange system. The main actors of this system are the developer (who usually manages the construction works as well), the landowner and flat buyers. According to interviews with local developers, instead of buying the land, the developer provides the landowner in return $20 \%$ to $30 \%$ of the built space. This percentage varies from city to city, as it is affected by the demand on local housing market. The revenues from the sale of the rest of the apartments cover the cost of the investment and provide the profit for the developer.

A key-point of this exchange system is that the developer does not need capital to acquire the land and the landowner has access to housing without paying for it. Moreover, this system reduces the investment risk caused by the unclear land property system and fluid land regulations (World Bank, 2007). As a developer comments, «it is very risky to buy the land before 
getting the building permit, because regulations aren't fixed and nobody knows if a permit will be issued» (F.T., developer, Gjirokastër, 2009). On the other hand, the landowner skips the complex, long and uncertain procedure of applying for a building permit, as the developer is responsible for the negotiations with the local authorities on the terms of land development, thus creating the conditions for satisfactory profits for all the actors.

Payment in advance is the main source of funding for the construction of apartment buildings. Considering that the demand for apartments is high and the offer on the housing market is low, potential buyers are willing to fund the project with their savings from migration, liquidation of their assets (house, livestock etc) or black-market activities. This practice reduces further the requirements for the initial investment capital and opens the door to small construction companies to take advantage of the exchange system in apartment buildings' construction.

Another common practice is the delivery of apartments in intermediate stages of construction, quite often just after the construction of the concrete frame of the building. Subsequently, buyers «do the works themselves in detail, walls, plumbing and electrical installations, while they have paid the contractor half the price» (H.M., public servant, Gjirokastër, 2009). This practice is profitable for both buyers and developers. The buyers adjust the flow of money to their financial capacity and housing needs. They reduce the total cost through the unpaid work of relatives and friends, as well as with the usage of construction materials they buy at affordable prices. The result of the different pace buyers proceed with construction works is the fact that many buildings diverge from the original architectural design and look like a patchwork.

As far as developers are concerned, the delivery of apartments at intermediate stages «is rather profitable, because selling the concrete frame of a building is like selling air» (F.T., developer, Gjirokastër, 2009) and so they have high and quick profits. This leads to the rapid development of their company and accelerates capital reinvestment, as "money flows faster" (S.M., developer, Gjirokastër, 2007). Moreover, the demand for investment capital and technical equipment is reduced and the risks of unexpected costs and delays caused by subcontractors who undertake parts of the final works of the project are eliminated.

Since the beginning of 2000s, this practice has been gradually abandoned and flats are sold completed or in the very final stage of construction. This shift is connected, on the one hand, with the improvement of the financial capacity of developers, due to the profits from housing sector, and, on the other hand, with the enhancement of households' funding resources due to migration remittances (King et al., 2005) and the development of the mortgage loan system.

\section{CONCLUSIONS}

The transition to a free-market economy in Albania brings housing production to the forefront as it fosters not only economic development, but also the integration of various social groups to urban development processes. A key-factor for this is the practices adopted for housing production.

Self-construction, informal housing and exchange practices in the construction of apartment buildings have been important practices for housing production in Albania in the 1990s and 2000s; practices that intertwine with each other. Selfconstruction is a significant tool for informal, as well as for commercial housing. Informal activities in housing production transect - in different ways - all types of constructions, from extensions of the old buildings to the construction of new dwellings and apartment buildings. The exchange system in the construction of apartment buildings turns to be profitable for all actors, namely landowners, developers and flat buyers, because it is based to a great extent on self-construction practices and informal activities.

Considering that formal market is underperforming, within the context of transition practices of housing production are based on exchange relations and develop beyond the existing legislative system. Non-marketized procedures dominate and set the ground for the development of capitalist relations and the growth of formal housing market in the long term. The dominance of these practices the first years of transition contribute to the creation of an introverted climate on the Albanian housing market, which, at the end of the day, protects households, small landowners, small construction companies and small developers from the pressure that could be applied by foreign investors, in contrast with other post-socialist countries (Andrusz et al., 1996; Hamilton et al., 2005).

Finally, practices of housing production pave the ground for interaction among various social groups and disperse the social and financial benefits of urban development. Although there are obvious differentiations regarding the way each social group participates in housing production and is affected by the surplus value, adopted practices involve landowners, developers, construction companies, builders, engineers, merchants and households in multiple ways. Moreover, they connect career opportunities with family strategies and housing needs with investment initiatives. As a result, housing practices, combined with high homeownership rates and the high quality of housing stock, contribute to the processes of social integration and foster social cohesion in the Albanian society; a very important fact, considering that the transition of Albania is a process full of tensions and conflicts. However, serious questions arise regarding spatial and environmental 
impacts of housing production as well as regarding safety issues and disaster-related vulnerability and risks; questions that recently have been posed on the top of the agenda of the central government and local authorities.

\section{AKNOWLEDGEMENTS}

This article builds on my $\mathrm{PhD}$ thesis at National Technical University of Athens in 2010 and fieldwork conducted in Albania between 2006 and 2017, funded by the National Technical University of Athens and Zosima Foundation. I am grateful to my supervisor, Maria Mantouvalou, emeritus professor at the National Technical University of Athens, for her decisive contribution to developing research methodology and elaborating research findings. I would also like to thank Loukas Triantis for sharing theoretical concerns and experiences on the field during the last years. Finally, thanks are due to all the informants for the discussions we had during fieldwork.

\section{REFERENCES}

Aliaj B. (2008), Misteri i Gjashtë (The sixth mystery). Tirana, U-Polis and Co-PLAN Publications. [in Albanian] ISBN 978-9995667603.

Aliaj B. (ed.) (2003), Making Cities Work! Tirana, ENHR and Co-PLAN Publications.

Andrusz G., Harloe M., Szelenyi I. (eds.) (1996), Cities after socialism: urban and regional change and conflict in post-socialist societies. Oxford, Blackwell Publishers. ISBN: 978-1557861641

Bertaud A. (2006), Urban development in Albania: the success story of the informal sector. URL: http:// alainbertaud.com/ wp-content/ uploads/ 2013 / 06/AB_Albania-Urban-informal-Sector-paper.pdf, Accessed on 08.10.2019.

Dalakoglou D. (2009), Building and ordering transnationalism: the 'Greek house' in Albania as a material process. In: Miller D. (ed.) Anthropology and the individual: a material culture perspective. Oxford: Berg, 51-68.

Dalakoglou D. (2010), Migrating - remitting - building' - dwelling: house-making as 'proxy' presence in postsocialist Albania. Journal of the Royal Anthropological Institute, 16(4), 761-777. DOI: https:// doi.org/ 10.1111/j.1467-9655.2010.01652.x

de Soto H. (2003), The mystery of capital: why capitalism triumphs in the West and fails everywhere else. New York: Basic Books. ISBN: 978-0465016150

Deda L. (2003), The new housing market in Tirana. In: Lowe S., Tsenkova S. (eds.), Housing change in East and Central Europe. Integration or fragmentation?. Aldershot, Ashgate Publishing Ltd., 171-180.

Hamilton I., Dimitrivska K., Pichler-Milanovic N. (eds.) (2005), Transformation of cities in Central and Eastern Europe: towards globalization. Tokyo, United Nations University Press. ISBN: 9789280811056

Harvey D. (2010), The enigma of capital and the crises of capitalism. Oxford, Oxford University Press. ISBN: 978-0199836840

Hodkinson S. (2012), The return of the housing question. Ephemera, 12(4), 423-444.

INSTAT (2004), People and work in Albania. Labour force, employment and unemployment in the transition. Tirana, INSTAT.

King R., Mai N., Schwandner-Sievers S. (eds.) (2005), The new Albanian migration. East Sussex, Sussex academic press. ISBN: 978-1903900789

Lowe S., Tsenkova S. (eds.) (2003), Housing change in East and Central Europe. Integration or fragmentation? Albershot, Ashgate. ISBN: 978-0754618140

Madden D., Marcuse P. (2016), In defense of housing. The politics of crisis. London, Verso. ISBN: 978-1784783549

Pengu R., Kelling S., Çakalli A. (2003), Bathore. Neighbourhood development agenda. Tirana, Co-PLAN Publications.

Rolnik R. (2019), Urban warfare. Housing under the empire of finance. London, Verso. ISBN: 9781788731607

SEED (2002), Albania - Building construction sector study and pipeline development. Sarajevo, South Europe Enterprise Development, International Finance Corporation and The World Bank Group.

Suraj D. (2015), Global financial crisis of 2007: the case of Albania. Mediterranean Journal of Social Sciences, 6(4), 130-137. DOI: 10.5901/ mjss.2015. v6n4p130

Tosics I., Hegedüs J., Remmert M. (2001), Housing in south-eastern Europe: between state and market. South-East Europe Review, 4, 23-150.

Triantis L. (2018), The post-socialist restitution of property as dispossession: social dynamics and land development in Southern Albania. Land Use Policy, 71, 584-592. DOI: 10.1016/j.landusepol.2017.10.056

Triantis L., Vatavali F. (2016), Informality and land development in Albania: land reforms and socioeconomic dynamics in a coastal settlement. Geografiska Annaler: Series B, Human Geography, 98 (4), 289- 303. DOI: 10.1111/ geob.12105

Tsenkova S., Antoni D. (2017), Building partnerships for social housing: growing housing needs and effective solutions for Albanian cities. Critical Housing Analysis, 4(2), 39-53. DOI: 10.13060/ 23362839.2017.4.2.385

UNECE (2002), Country profiles in the housing sector. Albania. Geneva: United Nations.

UN-HABITAT (2003), The challenge of slums. Global report on human settlements 2003. London and Sterling, VA, Earthscan Publications Ltd. ISBN: 9781844070374 
Vatavali F. (2017), Housing production and land property in Albania in transition. Social aspects of transformations in the city of Gjirokastër. The Greek Review of Social Research, 147, 41-74. DOI: 10.12681/grsr.11958
World Bank (2006), The status of land reform and real property markets in Albania. Tirana, The World Bank.

World Bank (2007), Albania urban sector review. Tirana, The World Bank. 